\title{
What Determines Job Creations from FDI Inflow to Africa?
}

\author{
Abdisalan Salad Warsame, $\mathrm{PhD}$ \\ Faculty of Economics \& Management Science, Somali National University
}

\begin{abstract}
Africa is a continent with a high proportion of the youthful population, stagnated economic growth, and high unemployment. The policymakers and researchers try to find the job creation determinants in Africa, which would be a potential solution for prolonged unemployment in Africa. The paper analyzed what determine the employment benefits from FDI inflow to Africa through examining the industry, the differentials of per unit FDI job creation among home countries of multinational enterprises (MNEs) as well as the host countries using pooled crosssectional data from Financial Times (2003-2017). The paper employs Ordinary Least Squared (OLS) and TwoStage Least Squared (2SLS) techniques. The key findings show that employment benefits from FDI inflow vary across the host countries due to different levels of local labor quality and industrial investment. The study also reveals that the per-unit FDI job creation varies across source countries because of MNE's labor-intensity and sector concentration heterogeneity. This sample covers all 54 African countries.
\end{abstract}

Keywords: Greenfield FDI, Brownfield FDI, Job Creation, MNEs, Sector.

DOI: $10.7176 / \mathrm{DCS} / 11-3-04$

Publication date:March $31^{\text {st }} 2021$

\section{Introduction}

Recently, Africa receives billions of US dollars investment inflow annually that improves many aspects of economic conditions in the continent. These investments are unequally scattered across the countries and their job creation magnitudes in the host countries differ due to their intrinsic characteristic differences. In Africa, information communication and technology (ICT) infrastructures have been in surge and expected to have different levels of development impacts on the countries in the continent. Basically, multinational enterprises (MNEs) are neither humanitarian organizations nor their investment locations are randomly selected but explicitly determined by the economic factors associated with the locations that show sustainable profitability for the firm.

The paper investigates the factors that determine jobs creation from FDI Inflow to Africa. In essence, FDI inflow is always good to the host country; the terms of agreements between local authorities and firm's representatives make an investment fair or unfair for the host economy. To examine the potential determinants of job creation from FDI inflow, the study employs various technical analyses resulting in an outcome that varied among determinants. To show industry effects on job creation from MNEs, the researcher classifies industries like Manufacturing, Primary, and Tertiary sector. The study also takes into account the effects of the home country, host country, and investment firms on job creation as well as the five sub-regions of Africa. The study analyzed some of MNE's home countries with special interests to compare their respective job creation in Africa. Further, this chapter examines the employment generation of FDI in the top 10 beneficiary host countries. For this chapter, the study applied a pooled cross-sectional data (2003-June 2017) from the Financial Times. The chapter employs Ordinary Least Squared (OLS) and Two-Stage Least squared (2SLS) techniques.

Then, it shows that the industrial sector is the most influential factor that impacts FDI job creation. The industry sector is an important factor that establishes its job creation because the sector determines the firm's laborintensive shares and required level of labor skills. Some industries are highly capital-intensive in generating fewer jobs than labor-intensive firms while other MNEs are high skilled labor-intensive, which some host countries may not be able to take full of employment benefits due to low skills of domestic workers. The study also reveals that the magnitude of job creation from MNEs varies across source countries, where the job creation of one unit of US dollars varies across destinations and sectors. The study also indicates that the M\&A's job creation is very small compared to greenfield FDI and explained these job creation disparities between FDI forms. Further, the developing countries create more jobs with their projects than MNEs from industrialized countries due to their high capital-intensity and home country's political influences on the host countries. This chapter contributes to the literature that the determinants of job creation from inward FD, the sector is an important factor impact MNEs' job creation in the host country; ceteris paribus.

Additionally, the contribution of the paper to the existing literature is that job creation from FDI projects depends on the form of FDI, sector, local labor quality, the host country's hiring policy, and investing firms, more especially the sector and the form of FDI. Besides that, the countries that got the least employment benefits from MNEs are the countries faced a sustained political and social strife. When this happens, it is difficult for that country to attract conventional FDI, and thus, it is most likely to get contractors and non-renewable natural resource seeking MNEs. 


\section{Literature}

To generate new jobs for locals, policymakers in developing economies struggle to attract more foreign direct investment (Javorcik, 2013) The beneficial effects of inward FDI on the host country also include knowledge effects on workers, technology transfer and most importantly, a gateway to the industrialization of Africa. Besides creating jobs for locals, FDI also stimulates economic growth, and knowledge (spillover effects) to indigenous firms, and pay higher wages than domestic enterprises. Africa is a continent of a high youthful population and a high rate of unemployment as a result of low economic productivity and poor economic policies.

In reviewed literature, there are numerous suggestive pieces of evidence and empirical demonstrations that FDI Inflow generates new jobs and creates good jobs paying a higher wage relative to indigenous firms. On individual perspective, a good job is a job that pays well and improves the living standard of the employee as well as allows the worker to grow to a higher position with greater earnings. And, a government perspective, good jobs are the jobs whose productivity is above the nation's average, "jobs with greater productive externalities, and jobs with potential for productivity growth" (Javorcik, 2013). Although a common belief about foreign-owned firms is that they are often more capital and knowledge-intensive, using sophisticated technology that allow them to penetrate a foreign market and outperform indigenous enterprises; their job creation effects on the hosting state depend on multifaceted issues that come from both the investing firm and hosting country. For the hosting country, if there is a policy for localizing workforces in place and availability of skillful local workers, this can probably increase job creation benefits from the FDI inflow. on the side of foreign-owned firms, their job creation benefits to the hosting state depend on a firm's intensity distribution (labor-intensive share in production) and also the firm's hiring preference for local or foreign workers.

More certainly, when there is no localizing policy for workers, foreign firms prefer foreign workers rather than locals for two reason; foreign workers are less likely to acknowledge spillover to domestic competitor firms than locals and secondly, firms engaging in illegal or substandard activities avoid indigenous workers because they might be reported to government officials and incur the firm a legal punishment. These cases are more phenomena in developing countries where governments are less or have no accountability to their citizens. There are so many foreign firms in the developing countries which their actual businesses are unknown. When we analyze the employment benefits from FDI inflow, it is important to classify it into its main two parts: Greenfield and Brownfield (M\&As) FDI. The differences of types of FDI in job creation are acknowledged and discussed in the following section.

\subsection{The Effects of Brownfield FDI on Employments}

The employment effects of merger and acquisition (M\&As) FDI inflow were discussed by many empirical works in different economies finding mixed results. A firm-level study in Denmark, found that the increase in foreign acquisition has a positive effect on job creation and employment effects are more on skilled workers than lessskilled workers (Bandick \& Karpaty, 2010). In Finland, domestic firm acquisition by foreign enterprises negatively impact on the percentage share of high skilled workers in the firm (Huttunen, 2007). Cross-border M\&As FDI leads to downsizing in manufacturing workers while the effect is weaker in the non-manufacturing sector (Eero \& Bockerman, 2008) $)^{1}$.

These previous studies were not comparing the on average effects of Brownfield FDI on job creation with Greenfield FDI, they have demonstrated the effects of cross-border M\&As on job generation. Additionally, some other studies found mixed findings of M\&As FDI effects on employment; negative effects in the U.S (Bhagat et al. 1990; Brown and Medoff 1988; and Lichtenberg and Siegel (1990); in France (Margolis 2006), positive effects in Italy (Ollinger et al. 2005; McGuckin \& Nguyen 2001; and McGuckin et al. 1995). In Austria, the foreign acquisition has no causal effect on employment growth in the manufacturing sector (Bellak et al., 2006). These findings are not necessarily representative to African context where labor quality and hiring process may differ from these developed countries. This study intended to indicate the effects of M\&As FDI on job creation in Africa revealing that it has a positive effect on employment. On the other hand, the great effects of Greenfield FDI on job creation are undisputed among research findings as discussed below.

\subsection{The Effects of Greenfield FDI on Employments}

In general, the employment benefits of Greenfield FDI inflow in the host countries are well-acknowledged among studies but these effects can vary across locations, sectors, and firms due to other pertinent factors. The Multinational Enterprises (MNEs) are often more skilled and capital intensive than domestic enterprises, so they may have lower shares of skilled and unskilled relative to domestic firms (Zulfiu,2015). This implies that MNEs are more machine-intensive compared to the domestic firms that engage in the same type of activities.

In Italy, Piscitello and Rabbiosi (2005) found that direct foreign investments increase employments, wage,

\footnotetext{
${ }^{1}$ When we considering inward FDI effects on job creation, treating FDI as an aggregate would produce a misleading outcome. The brownfield FDI occurs when foreign firm and domestic firm merges or/and acquired indigenous firm by the foreign company, creating less or nothing new economic activities. Some M\&As FDI may downsize or replace some current employees during the restructuring process.
} 
and economic productivity; similarly, in Indonesia (Arnold and Javorcik,2009). The Greenfield FDI inflow changes labor markets of the hosting country, this happens in low tech economies where wages and skills are low and/or in high tech where they pay higher wages for high-skilled employees (Amoroso \& Pietro, 2018). Regardless of the local economic development in the host country, the FDI inflow brings some type of competition compelling other firms to carry out some innovative works in technology, management, and hiring procedures. In 2016, Greenfield FDI inflow to EU Members created approximately 230,000 new jobs (EU Commission report, 2017). In China, a study of manufacturing firms' effects on employments found that FDI has a positive impact on employment growth and these effects on employments from the MNEs depend on the firm's activities (Karlsson, el at. 2007) ${ }^{1}$. The same study found that there is an indirect impact on employment in indigenous firms through spillover effects.

Additionally, a good FDI Inflow does more than job creation; it brings greater knowledge externalities to the hosting country. According to (Javorcik, 2013), there are two forms of externalities, and perhaps the most important one for a country is knowledge effects, which occurs when knowledge generated by foreign companies is applied by domestic firms without compensating the foreign firms for the use of their knowledge. Indigenous firms may acquire new knowledge of technology, management skills, and new production method from foreigninvesting firms through observing actions of FIFs and hiring former workers of FIFs. FIFs may also transfer some knowledge or technology to their local supplier firms free of charge. The second type of externality is pecuniary, this form of externality happens when FIFs and indigenous negotiate over price properly in a functioning market that will lead to greater productivity of indigenous enterprises.

To generate new jobs for locals, policymakers in developing economies struggle to attract more FDI (Javorcik, 2013). The beneficial effects of Inward FDI on the host country also include knowledge effects on workers, technology transfer and most importantly, a gateway to the industrialization of Africa. Besides creating jobs for locals, FDI also stimulates economic growth, and knowledge (spillover effects) to indigenous firms, and pay higher wages than domestic enterprises. Africa, as a continent with a high youthful population and a high rate of unemployment, doesn't benefit much as a result of low economic productivity and poor economic policies. The continent remains a net FDI receiver and strives to attract more FDI inflow to create new jobs for locals. Nevertheless, there is an unsubstantiated widespread allegation against FDI inflow to Africa for poor job creation. Chinese firms are accused of hiring their workers from China while western countries are in Africa for natural resource exploitation that heavily relies on machinery. Therefore, the objective of this chapter was to investigate what determines jobs creation from FDI Inflow to Africa? FDI inflow is always good to the host country; however, the terms of agreements between local authority and firm make an investment fair or unfair.

\section{Brief Employment Conditions in Africa}

The unemployment condition in Africa attracts the attention of international organizations and policymakers. The rampant unemployment in many parts of Africa forced many young people to join the underground economic activities, extremists, migrating recklessly, and participating in the civil war. Africa's workforces are expected to expand more than 14 million annually (ILO, 2019). Therefore, Africa has to create more than 13 million new jobs annually to prevent the rate of unemployment from rising. The labor forces experience many employment challenges including low-quality jobs, job insecurity, and underemployment. Approximately 37\% of the globes extremely working poor people reside in sub-Saharan Africa, where $34.3 \%$ of the region's working people live below the poverty threshold of US\$1.90 per day and 64\% live less than US\$3.10 a day. Northern Africa's unemployment rate remains the highest of all regions at $12.1 \%$ decreasing from $12.5 \%$ in 2014 . And in Northern Africa, over one-third of workers are in vulnerable employment.

In sub- Saharan Africa the unemployment rate increased slightly to $7.4 \%$ in 2015 , from $7.3 \%$ in 2014 (ILO, 2016). The vulnerability of employment remains prevalent in sub-Saharan Africa at almost $70 \%$ of total employed, beating the global average of 46.3 percent. The touching issue in Sub-Sahara Africa about employment is poorquality job due to lack of well-functioning labor markets, social protection schemes, and labor rights protection bodies. Many workers accept a poor-quality works because there are no other options available. In African developing countries, the illicit activities are skyrocketing and they are accounted for more than 30\% of total GDP in the developing countries (Investopedia).

\footnotetext{
${ }^{1}$ The Greenfield FDI occurs when a firm establishes new production facilities from scratch in a foreign land, creating new activities in host economies. These new economic activities include hiring all the firm's employees and producing new products/services.
} 


\section{Unemployment Rate, total (\% of total labor force)}

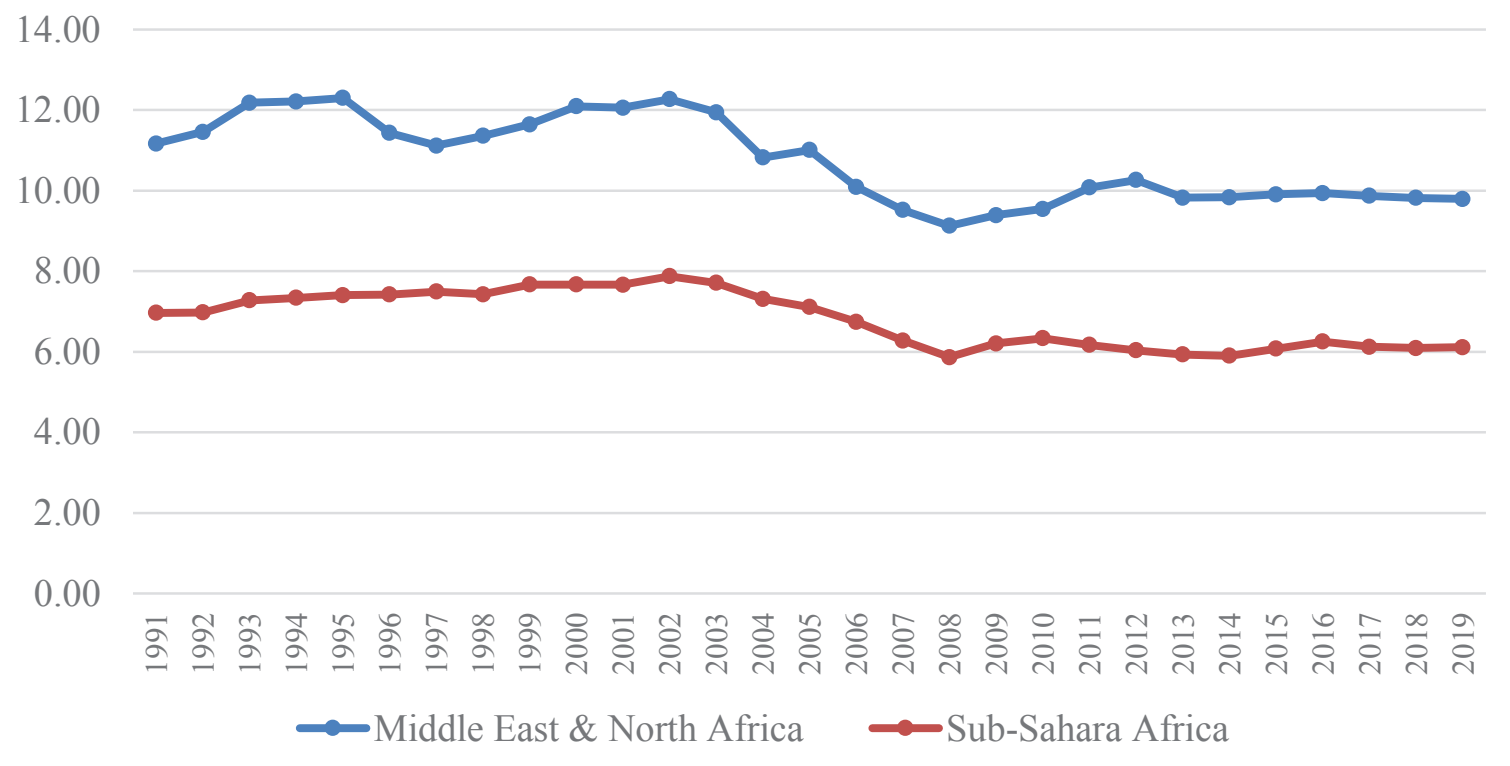

Figure 1: Unemployment Rate, Total (\% of total labor force) (1991-2019)

Source: World Development Indicators, December 20, 2019

Source: author's computation

As this figure indicates, North Africa has the highest unemployment rate in Africa. The mean of this figure is 10.76 for North and 6.81 SSA with a standard deviation of 1.04 and 0.69 , respectively. According to data, the highest unemployment rate over the last three decades was 12.3 in North Africa and around 7.9 in SSA. Finally, Africa needs to adopt a model suitable for its unique problems to achieve sustainable employments in transforming the economy from traditional to the modern economy, through quality education and technology. Unless African leaders change their mindsets, nothing good is going to be materialized.

\section{Data and Analysis}

Greenfield FDI data derived from fDi Markets (Financial Times), is the most comprehensive online database of cross-border Greenfield investments, covering all countries and sector worldwide. This data is a firm-level that provides the firm's characteristics (basic information including investment amount and jobs created) covering the period from 2003-to- June 2017. The data is collected in real-time as announced by a company and provided as a daily e-mail newswire and live updates online. Industrial classification is classified according to its cluster, sector, sub-sector and business activity, based on North American Industry Classification System (NAICS 2007). fD $i$ Markets tracks information on capital investment and direct jobs associated with an FDI project. This chapter used exchange rate data from central banks of South Africa and Nigeria for an instrumental variable; it is a monthly average exchange rate.

Even though the data was for half a year in 2017(Jan-June 2017), all sectors indicated sharply decreasing patterns in 2017. The data downward should not be understood as a decline of FDI inflow to Africa. The sharp decline of data in 2017 might be caused by the undocumented number of investments record since by that time the year 2017 hasn't come to an end, and thus a full investment was impossible. Therefore, it is quite sensible to give more attention to the data movement patterns before 2017. The data in question was collected in 2017 , so some details might not be available at the time of data analysis. Even though the data shown a decreasing pattern in 2016, such a huge change in investment in 2017 is unjustifiable. All different sectors dramatically decreased and fewer investments than in the previous years. Besides, this decline has existed since 2016, so one can also explain it as diminishing business opportunities in Africa, particularly in some countries as well as some sectors. Lastly, the continuing FDI decline in Africa may also be an indication of the anticipated economic shock in the near future.

This empirical work applies firm-level data sourced from the Financial Times. The data contains basic information about the investing-firms such as parent company, origin country, industry, amount of capital, created jobs and chosen location. The study uses the standard Ordinary Least Squared (OLS) and other techniques for robustness checks. The data were pooled from more than four-thousand different enterprises from all over the world including Africa itself, making a total of 9,616 investments in 39 different industrial sectors across the African continent. For simplicity, the industries are categorized into three main branches; Manufacturing, Tertiary and Primary Sector according to "International Standard Industrial Classification of All Economic Activities". 
Under this study primary sector stands for only mining and quarrying. For total observation, manufacturing is $34.5 \%$, tertiary $53.5 \%$, and natural resource $12 \%$.

Table1 shows the shares of FDI Capital and Job creation among industries. It shows manufacturing sector earned $15 \%$ of total FDI capital and created $44 \%$ of total jobs, where $42 \%$ of FDI went to tertiary sector creating $33 \%$ of total jobs while $43 \%$ was invested in mining \& quarrying that created $23 \%$ of total jobs. The result in Table indicates that manufacturing earned the least amount of capital investment but created higher jobs than other sectors followed by the tertiary sector, while the natural resource is both the least job-generating and huge capital required sector. Most manufacturing is primary manufacturers (e.g., wood and garment products) that create wideranging job opportunities from unskilled to highly skilled labors. Since Africa faces protracted Brain-Drain, primary manufacturing is good for unskilled and low skilled labors in Africa. The service industry requires a mixture of high and low skilled workforces such as doctors, consultants, engineers, teachers, researchers, and lawyers plus some blue shirts such as construction workers. Africa has difficulty when it comes to knowledgebased and high skills requiring jobs because it has lost its highly educated and professional people to the world.

\section{Table 1: Percentage Shares of FDI and Job Creation by Sectors}

\begin{tabular}{lcc}
\hline Industry & Capital (\%) & Job Creation (\%) \\
\hline Manufacturing & $15 \%$ & $44 \%$ \\
Tertiary & $42 \%$ & $33 \%$ \\
Mining \& Quarrying & $43 \%$ & $23 \%$ \\
\hline
\end{tabular}

Source: Author's calculation

Overall, over the years of study, total Greenfield FDI is about \$1,021,129.677 US dollars and the number of jobs created is 1,984,043. On average, per unit FDI job creation is 1.94. This means one unit (million) of Greenfield FDI inflow to Africa approximately creates 194 jobs. African FDI represents just 9\% of total FDI while foreign FDI is $91 \%$. Interestingly, their respective job creation is similar to their percentage shares of FDI while their Per Unit FDI job creation is the same and equals 1.94.

The job creation magnitude also depends on the form of FDI Inflow the host country receives. FDI inflow comes into two forms: Brownfield and Greenfield; the Brownfield FDI is merger and acquisition of domestic firms, and Greenfield FDI occurs when foreign firms establish a new production/service facility in a foreign land. In general, manufacturing and service sectors create the most jobs in any developed economy. The sectors that contribute the largest percentage of GDP also create more jobs. For developed economies (excluding Gas \& Oil exporting countries), more than $80 \%$ of GDP are accounted from manufacturing and service sectors and rest percentage are from primary sectors. According to the U.S. Bureau of Labor Statistics, manufacturing and services sectors are major job generators, accounting for $7 \%$ and $81 \%$ in 2016 , respectively. Firms concentrating on the primary sector, produce a negligible number of jobs when compared to another sector. In South Africa, manufacturing GDP share declined and the unemployment rate became significant (Black, Craig \& Dunne, 2016).

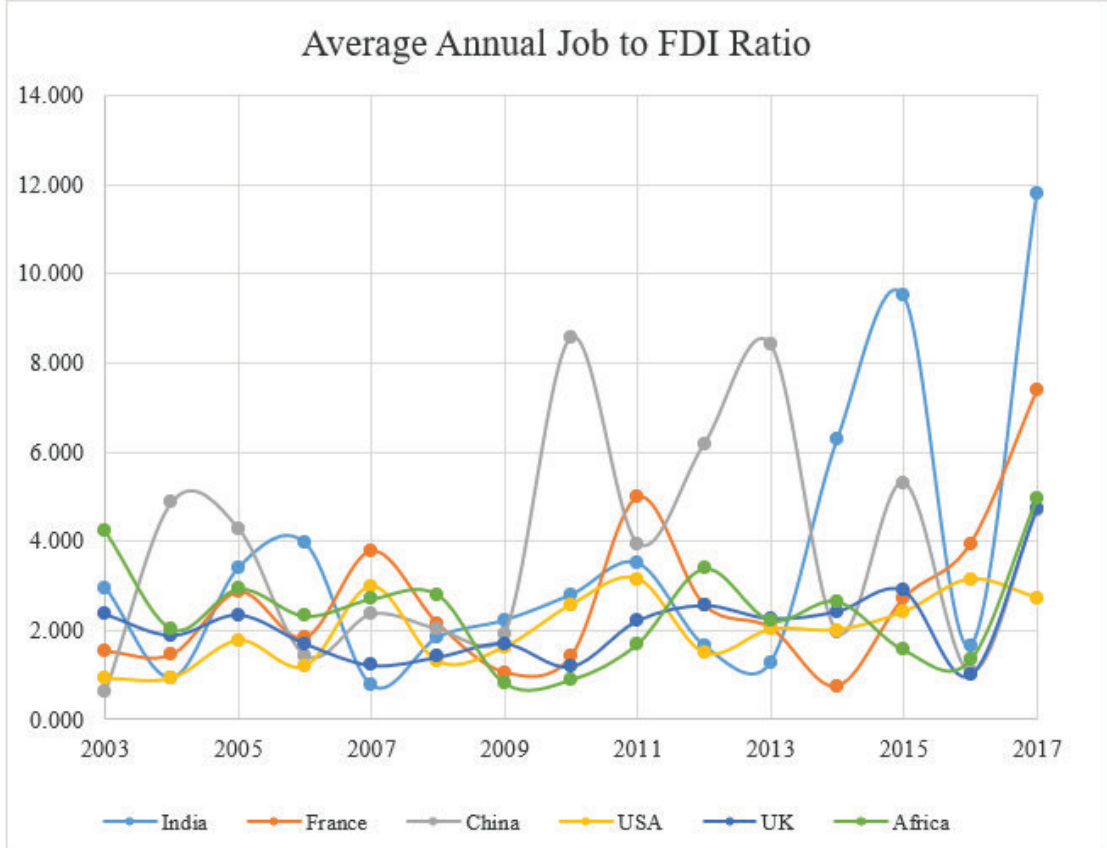

Figure 2: Annual FDI job Creation Comparison of Selected Countries (Job-to-FDI Ratio)

Source: author's computation

This is average annual job creation to FDI inflow ratio (per unit FDI job creation) over 14.5 years. The greater 
the job-to-FDI ratio is, the better. This means, when the ratio is high the MNE creates more jobs with less amount of capital and vice versa. The job-to-FDI ratio of India and China fluctuate relative to other countries. Regardless of average annual ratio volatility, the FDI from India and China indicate more efficiency in job creation. Africa represents African countries that invest in other African countries.

The figure provides insights about movement patterns of Greenfield FDI inflow and its job creation during the sampled. It is an annual average of FDI inflow and its job creation indicating that employment benefits from MNEs have a direct correlation to the capital amount of investment. The implication is that if the size of capital inflow increases, the job creation increases as well, and vice versa while keeping other factors constant.

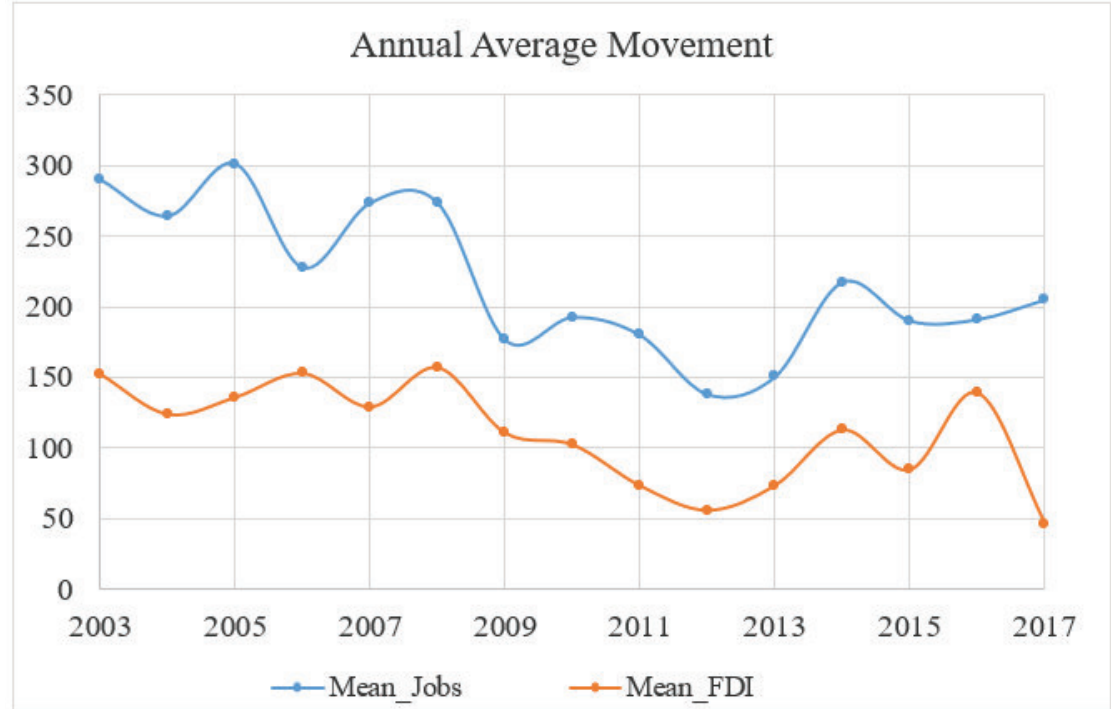

Figure 3: Annual Mean of Greenfield FDI and Created Jobs Over Time (2003-June 2017)

As this figure depicts; FDI inflow and its job creation moving together up and down. As explained in the following summary statistics, the standard deviation of the data is so large that it requires readers to read with caution. The large value of standard deviation is quite common in FDI data due to timing which is a long time and random collection. During a long time of data collection, there might be some economic and political factors changing in the host country and in the source country. These can cause a big data standard deviation. Whenever the time passage gets longer, the variation of data may increase because of factors changing in-between times, which inflate the standard deviation. The FDI inflow to a country depends on the level of relationship between two countries that can change as well as the global economic condition and the host economies and home economies. These factors affecting FDI inflow variability are uncontrollable.

\subsection{Summary Statistics}

Table 4.1 provides the summary statistics that analyzes the variables employed in the paper. The study mainly used the Greenfield FDI inflow to Africa, which is a key variable in this study because the Greenfield FDI generates more jobs than the Brownfield FDI. The dependent variable is a log of jobs created by MNEs. The standard deviation values of both the outcome and key variable (FDI) are small indicating that the data spread out from the mean is small. The small values of standard deviation imply the mean of the data is a good representative and thus, the estimation results could also be more realistic. 
Table 2: General Summary Statistics

\begin{tabular}{|c|c|c|c|c|c|}
\hline Variables & $\mathrm{N}$ & MEAN & SD & MIN & MAX \\
\hline \multicolumn{6}{|l|}{ Outcome Variable } \\
\hline Log of Jobs & 9,616 & 4.09 & 1.53 & 0.00 & 9.47 \\
\hline \multicolumn{6}{|l|}{ Treatment Variable } \\
\hline Log of Greenfield FDI & 9,616 & 2.98 & 1.64 & -4.27 & 9.90 \\
\hline Log of Brownfields FDI & 8,120 & 8.44 & 1.78 & 1.06 & 12.10 \\
\hline \multicolumn{6}{|l|}{ Instrumental Variable } \\
\hline Exchange Rate & 2,387 & 40.78 & 56.89 & 5.63 & 319.8 \\
\hline \multicolumn{6}{|l|}{ Control Variables } \\
\hline Industry & 9,616 & 18.53 & 9.83 & 1 & 39 \\
\hline Firm & 9,616 & 2105.9 & 1237.1 & 1 & 4258 \\
\hline Country of Origin & 9,616 & 78.77 & 37.08 & 1 & 126 \\
\hline Host Country & 9,616 & 31.71 & 16.28 & 1 & 56 \\
\hline Project Type & 9,616 & 2.91 & 0.31 & 1 & 3 \\
\hline
\end{tabular}

Notes: The variable of interest is Greenfield FDI inflow. The IV variable is a monthly average exchange rate of South Africa and Nigeria. The project types are dummy variables that classify the projects as a new project, expansion or co-location. The measuring units for outcome variable is per thousand while the FDI inflow is per million in US Dollars.

Although there is no direct correlation between the mean and the standard deviation of data, the mean indicates the center of the data; standard deviation reflects the dispersion of data sets, yet there are still some useful indications that their values indicate in statistics. The difference between the mean and standard deviation variables tell us the data distance to the average. The following Table 3 provides summary statistics for sub-regions, which show that the means of both independent and outcome variables are higher than the standard deviation implying that the data scattered around the mean implying a good indication for better quality representativeness of the results.

The FDI inflow and job creation have different values of means and standard deviations across the regions. Job creation and FDI variables have the highest standard deviation in the central Africa region compared to other sub-regions of Africa. Generally, when the variables have a small standard deviation, it is said to be a good representative and generalizable and vice versa.

Table 3: Summary Statistics by Subregions

\begin{tabular}{lccccc}
\hline \hline & \multicolumn{2}{c}{ Log of FDI } & \multicolumn{2}{c}{ Log of Jobs } \\
\cline { 2 - 5 } Regions & $\mathrm{N}$ & Mean & SD & Mean & SD \\
\hline Eastern & 2,023 & 2.84 & 1.50 & 3.95 & 1.46 \\
Central & 680 & 3.21 & 1.84 & 4.00 & 1.70 \\
Southern & 2,433 & 2.78 & 1.58 & 3.86 & 1.47 \\
Northern & 2,903 & 3.13 & 1.68 & 4.36 & 1.54 \\
Western & 1,577 & 3.08 & 1.71 & 4.16 & 1.52 \\
\hline
\end{tabular}

Further, these summary statistics of sub regions are intended to provide further insights about empirical results.

The mean values and standard deviation differences in sub regions do not always determine the FDI job creation in which high values of standard deviation data can generate more jobs than data that has a smaller standard deviation. The following empirical estimation section will explain and provide further clarification about the variables and their applications.

\subsection{Empirical Estimation}

To answer the hypothesized research question of what determines the job creation from FDI inflow to Africa, the study employed several variables influencing the outcomes and analytical techniques. As shown in the above table 4.2, the variables consisted of four main parts such as the outcome, treatment, controls, and instrumental variable. This study examines direct job creation from FDI inflow to Africa after MNEs have invested in the country.

The variable of interest that influences the outcome variable is Greenfield FDI inflow which this chapter focuses on. Both the dependent and key variables were logged to control the coefficient size and for easier interpretation. The study used cross-sectional pooled firm-level data and OLS techniques. During the analysis, the suspected causality issue was treated using the Two-Stage Least Squared (2SLS) model and the average monthly exchange rate of sample countries.

The study further considered other factors that have an impact on job creation from MNEs after key variable such as sector, the host country, and the country of origin. This intended to reveal the magnitude of employment differences from FDI if the same amount of capital were invested in the main three economic sectors. Further, the study found that there are some intrinsic specific effects associated with the destination including employment 
policy, local labor quality, and legal framework as well as economic institutions. About MNEs prospect, there are also other factors associated with the investment firms which affect the outcome including managerial procedure, hiring preference, and intensity distribution. The following section provides robust results of the above-mentioned issues.

\subsubsection{Model Specification}

To answer what determines the job creation from FDI Inflow to Africa, the paper applied micro-level and pooled cross-sectional data of Greenfield FDI Inflow to Africa covering a period of 2003-to-June 2017 using Ordinary Least Squared (OLS) model. The study also employed Two-Stage Least Squared (2SLS) for treating potential endogeneity. Similar theoretical discussion and empirical methodology was applied in previous relevant studies by Karlsson (2007), and Chen, Ge, and Lai (2010).

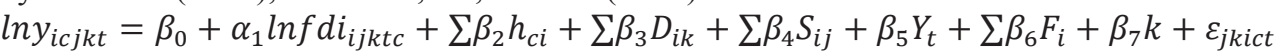

Where lny $y_{i c j k t}$ represents jobs creation outcome of firm $i$ from country c invested in sector $j$ in destination $k$ at time $t$. The $\ln f d i_{i j k t c}$ is a Greenfield FDI inflow to Africa while $L n$ is log for both dependent and treatment to control number size. The $h_{c i}$ is a dummy for firm's origin country and capture the different magnitude effects on employment across the origin countries. $D_{i k}$ is a hosting country dummy that equals one if firm $i$ invests in destination $k$, zero otherwise, and it captures location-specific effects on job creation. $S_{i j}$ is dummy for sector that equals one if firm $i$ invests in sector $j$ and zero otherwise, and captures the sector-specific effects of industry on job creation. $Y_{t}$ is year dummy for time effects. $F_{i}$ is investing firm and captures firm's effects on job creation.

The firm's level effects on employments includes intensive distribution, top manager nationality and financial reporting language that may restrict local workers. The intensity percentage share of the firm on average are an important input in this model because intensity share is one of job creation determinants. Since, the researcher couldn't find data for firm's intensity input in production, the study used parent company of investing firm as proxy dummy for firm's production intensity distribution. The $k$ is interaction term among independent variables. Finally, $\varepsilon_{j k i c t}$ is the unobservable error term and $\beta_{0}$ is constant term.

\section{Empirical Results and Robustness Checks}

Table 4 is the basic model of the study and results are shown from column 1 to column 7. Column 1 is a basic result and the full sample showing that one-unit increase in Greenfield FDI inflow to Africa results in a $0.728 \%$ increase in the job creation keeping all other variables unchanged. After controlling the fixed effects of control variables, the industry becomes the most impactful control variable on job creation from MNES relative to other control variables (see column 2). In nature, manufacturing and tertiary sectors contribute a high percentage of employment to any economy while the primary sector is known as the least employment contributing industry as the study will show in the latter section.

Therefore, the firm's industry is regarded as one of the main determinants of job creation volume. Other potential factors affecting a firm's job creation level include the host country localizing workforce policy, local labor quality and firm's labor intensity percentage share in production. The skills and education quality of local workers can magnify the employment benefits which the host country can get from inward FDI. To create appropriate jobs for domestic people, it is important to study what type of skills your unemployed people have for you to encourage the MNEs that can generate the employment opportunities that local people can perform. Even though all inward FDI are important for development, they still have a different level of importance and the host country may not be able to take full benefits of every inward FDI. 
Table 4: Job Creation Estimation Results by Greenfield FDI Inflow

\begin{tabular}{lccccccc}
\hline \hline Variables & $(1)$ & $(2)$ & $(3)$ & $(4)$ & $(5)$ & $(6)$ & $(7)$ \\
\hline Log of FDI & $0.728^{* * *}$ & $0.654^{* * *}$ & $0.729^{* * *}$ & $0.728^{* * *}$ & $0.730^{* * *}$ & $0.728^{* * *}$ & $0.665^{* * *}$ \\
Inflow & $(0.00643)$ & $(0.00678)$ & $(0.00639)$ & $(0.00643)$ & $(0.0064)$ & $(0.00642)$ & $(0.00668)$ \\
Constant & $3.103^{* * *}$ & $3.256^{* * *}$ & $2.605^{* * *}$ & $3.170^{* * *}$ & $3.446^{* * *}$ & $3.017 * * *$ & $2.105^{* * *}$ \\
& $(0.802)$ & $(1.023)$ & $(0.108)$ & $(0.803)$ & $(0.807)$ & $(0.803)$ & $(0.0227)$ \\
Observations & 9,609 & 9,609 & 9,609 & 9,609 & 9,609 & 9,609 & 9,609 \\
R-squared & 0.739 & 0.565 & 0.729 & 0.738 & 0.732 & 0.737 & 0.508 \\
Industry FE & Yes & No & Yes & Yes & Yes & Yes & No \\
Home Country & Yes & Yes & No & Yes & Yes & Yes & No \\
FE & Yes & Yes & Yes & No & Yes & Yes & No \\
Firm FE & Yes & Yes & Yes & Yes & No & Yes & No \\
Host Country & FE & Yes & Yes & Yes & Yes & No & No \\
Year FE & Yes & Yes & Yes & Yes & Yes & Yes & No \\
Interactions FE & Yes & & & & & & \\
\hline
\end{tabular}

Notes: The Column 1 is basic results and the study controls the FE of all control variables. As column 2 shows, Industry is most influencing control variable compare to other controls. The dependent and treatment variables are both logged to control number size. The unit of FDI is per million of US Dollars.

Significance level: $* * * \mathrm{p}<0.01, * * \mathrm{p}<0.05, * \mathrm{p}<0.1$.

Table 5 is the job creation comparison between Greenfield and Brownfield FDI inflow to Africa. The merge $\&$ acquisition FDI is found by subtracting Greenfield FDI from total FDI inflow to Africa in the period of 2003to-2015 because total FDI is a combination of Greenfield and Brownfield FDI. As column 2 in Table 5 shows, 1\% increase in Brownfield investment increases the outcome by $0.075 \%$ while a $1 \%$ increase in the amount of Greenfield FDI on average leads to a $0.728 \%$ increase in the number of jobs created, ceteris paribus. The considerable amount of job creation differences between M\&As and Greenfield FDI; is because the M\&As are purchasing/merging existing firms or buying shares/line of production from existing companies and this type of investment creates negligible new economic activities compared to the Greenfield one. The economic activity of Brownfield FDI is already absorbed by the economy. Conversely, the Greenfield FDI is an investment that starts its business activities from scratches such as constructing a new factory or company. This type of investment brings more employments opportunities and new economic activities because it hires all its workers and provides new products or services that impact the economy more than M\&As do.

Table 5: Job Creation Comparison of Greenfield and Brownfield FDI Inflow (2003-2015).

\begin{tabular}{lcc}
\hline \hline Unit of Analysis & Greenfield FDI & Brownfield FDI \\
\hline Variable & $(1)$ & $(2)$ \\
\hline & $0.729^{* * *}$ & $0.0757^{* * *}$ \\
Observations & $(0.0104)$ & $(0.00528)$ \\
R-squared & 8,690 & 8,116 \\
Firm FE & 0.739 & 0.999 \\
Industry FE & Yes & \\
Host Country FE & Yes & Yes \\
Year FE & Yes & Yes
\end{tabular}

Notes: The period of FDI Inflow to Africa in this Table is from 2003 to 2015. it applied to show effects of Greenfield and Brownfield FDI on employment. Brown FDI is calculated from Total FDI inflow to Africa subtracted by Greenfield FDI. Total FDI Inflow is country level data while Greenfield FDI inflow is firm level data. Therefore, to get Brownfield from the Total FDI, Greenfield FDI was subtracted from total FDI Inflow over 2003-2015. OLS and FE model were used in Column (1) and column (2), respectively. Significance level: $* * * p<$ $0.01, * * \mathrm{p}<0.05, * \mathrm{p}<0.1$.

Intuitively, M\&As and Greenfield FDI inflows have an initial difference in economic activities which results in their job creation disparity. As one can see in the literature, their job creation differences are more pronounced in economic studies. Besides that, the chosen industry for investment is also a key determinant of job creation volume in Africa due to low local labor quality and sector's labor intensity needs in nature. Table 6 demonstrates 
per million US dollar's job creation when one invests it in different industries, following the "International Standard Industrial Classification of All Economic Activities", the study classifies industries into three main categories as the below table illustrates.

lnjob $_{i t}=\alpha_{0}+a_{1} \log f d i_{i} *$ industry $_{j}+\sum \alpha_{2} k+\sum \alpha_{3}$ Inter $+u_{i}$.

Where $\operatorname{lnfdi} i_{i}$ industry in $_{j}$ is the $\log$ of FDI inflow with the interaction of industrial sector $j$ that firm $i$ invests in. This model shows the per-unit FDI job creation in different sectors. In other words, this is to analyze the job creation differences of one million FDI inflows across the sectors in Africa. The $k$ represents the control variables in the model (see equation 1) and the Inter devotes the interaction term. The $\alpha_{0}$ is constant coefficient and $u_{i}$ is the unobservable term. The researchers interact terms when one variable's effects depend on other variable's values.

Table 6: Per Unit FDI Job Creation by Industrial Sector

\begin{tabular}{lccc}
\hline \hline Industry & Manufacturing & Tertiary & Primary \\
\hline FDI Inflow*Industry & $0.789^{* * *}$ & $0.625^{* * *}$ & $0.585^{* * *}$ \\
& $(0.0103)$ & $(0.00926)$ & $(0.0196)$ \\
Constant & $2.885^{* * *}$ & $1.656^{*}$ & 1.593 \\
& $(0.885)$ & $(0.992)$ & $(1.287)$ \\
& & & 1,146 \\
Observations & 3,320 & 5,143 & 0.672 \\
R-squared & 0.725 & 0.594 & $\sqrt{ }$ \\
Host country & $\sqrt{ }$ & $\sqrt{ }$ & $\sqrt{ }$ \\
Home country & $\sqrt{ }$ & $\sqrt{ }$ & $\sqrt{ }$ \\
Time & $\sqrt{ }$ & $\sqrt{ }$ & $\sqrt{ }$ \\
Firm & $\sqrt{ }$ & $\sqrt{ }$ & \\
Interactions & $\sqrt{ }$ & & \\
\hline
\end{tabular}

Notes: Primary represents natural resource throughout this study. FDI inflow is a logged Greenfield FDI.

Significance level: $* * * \mathrm{p}<0.01, * * \mathrm{p}<0.05, * \mathrm{p}<0.1$.

According to Table 6, the jobs creation of one million US Dollars of inward FDI invested in these different sectors, sizably vary across industries due to their discrepancies in demanding for skill levels and lobar-intensity in production. Multinational enterprises create 81.6 percent of new jobs with their manufacturing investments. Manufacturing activities create wide-ranging jobs from low or no skill to high skills requiring jobs. Africa in particular, manufacturing investments are more preferable projects where vast unskilled and low-skilled workforce is available. As supporting evidence, Table 1 illustrates that the manufacturing sector is the least invested industry but a major job creator in Africa, earning just 15 percent of total FDI inflow while creating 44 percent of total jobs. More than half of the total inward FDIs are tertiary or service sector, second major generating investments. Although the service sector is a high skill-oriented industry, it is still well-known for a great role in job creation in the economy. For instance, hotels, hospitals, law firm and academic institutions are among service providers but require highly skilled workers.

Additionally, the manufacturing sectors have the smallest FDI mean and standard deviation compared to the service and primary sectors. In job creation summary statistics, manufacturing sector has the second-largest job creation mean and the biggest standard deviation. Having the smallest mean of capital with the smallest standard deviation relative to other sectors and the largest standard deviation in job creation implies that manufacturing MNEs generate more wide-ranging jobs with less capital than other sectors. However, the overall information of the summary statistics shows that the data was badly contaminated by outliers implying weak representativeness.

In Table 7, the chapter analyzes the job creation of MNEs from five countries with special interests in the study. Chronologically arranged, MNEs from India take the leading position of job creation with their projects followed by those China while the MNEs from UK and USA are the least job-creating projects. Every country may have a different way of doing business and managerial procedures that affect the number and position local workers can hold. MNEs from different countries may concentrate on different industrial sectors. Western MNEs are more capital intensive and natural resource-oriented comparing to MNEs that come from developing countries that cause disparities of job creation magnitudes among source origin countries. The western countries may have political influence on the host country and therefore the host country might not able to bargain hard with the MNEs from these influential countries for gaining more jobs for locals. Further, some firms bring their workers from home country, specifically the contractor MNEs for many reasons including concealing some internalized expertise and specialist workers. 
Table 7: MNE's Job Creation Comparison by Source Country

\begin{tabular}{lccccc}
\hline Fund Country & India & China & France & USA & UK \\
\hline Logged FDI*Origin & $0.142^{* * *}$ & $0.0820^{* * *}$ & $0.0757^{* * *}$ & $0.0753^{* * *}$ & $0.0731^{* * *}$ \\
& $(0.018)$ & $(0.014)$ & $(0.006)$ & $(0.006)$ & $(0.007)$ \\
Constant & -121.1 & -72.86 & 152.6 & $277.5 * *$ & 412.2 \\
& $(218.2)$ & $(287.8)$ & $(100.2)$ & $(123.5)$ & $(275.6)$ \\
$\mathrm{N}$ & 456 & 349 & 899 & 1,180 & 978 \\
R-Squared & 0.73 & 0.72 & 0.75 & 0.67 & 0.74 \\
Time & Yes & Yes & Yes & Yes & Yes \\
Origin countries & Yes & Yes & Yes & Yes & Yes \\
Host Countries & Yes & Yes & Yes & Yes & Yes \\
Firms & Yes & Yes & Yes & Yes & Yes \\
Interaction Terms & Yes & Yes & Yes & Yes & Yes \\
\hline
\end{tabular}

${ }^{1}$ Chronologically, the job creation of FDI inflow to Africa varies across the source origin countries due to their differences in orientation and concentration. This result shows that India and China projects are the best job creators while American and British FDI are least job creating according to this data. The results contradict the accusation against Chinese enterprises in Africa for bringing workers from home country creating fewer job for locals. Significance level: $* * * \mathrm{p}<0.01, * * \mathrm{p}<0.05, * \mathrm{p}<0.1$.

From 2003 to June 2017, Chinese enterprises have created total jobs of 147,920 jobs with their 349 projects in more than thirty countries in Africa. Among these projects, 161 manufacturing projects accounted for generating 104,519 new jobs $(71 \%)$ of total jobs, followed by construction sector 13,001 (9\%) jobs with 11 projects and extraction 10,317 (7\%) with 16 projects. Although, countries benefited from the Chinese projects at different levels during the time, the volume of created jobs in hosting country depends on the type of projects it receives. For instance, most manufacturing projects went into South Africa, Ethiopia, and Nigeria, these manufacturing projects receiving countries also recorded the highest jobs creation rate.

In table 8 , the study analyzes the FDI job creation in the top-ten beneficiary host countries finding the different magnitude of job creation among countries. Employment benefits from FDI inflow depend on the type of investment projects the host country receives and the skills level of local workers. MNEs are required to hire the local people or giving local workers a high percentage of total employees of the company by some host countries. The unfortunate thing is that localizing workforce data and the countries applying it, is neither given nor available; that makes it difficult to know its real effects of the host country on job creation from MNEs. For example, the top beneficiary countries have received different industries, manufacturing activities in Algeria is $52 \%$ of its total investments and 36\% in the service sector. In Morocco, 44\% and 52\% are manufacturing and service, respectively. Angola has the lowest manufacturing projects, 25\% manufacturing and 61\% service activities. For low human capital quality countries can't take full advantage of tertiary related investments because these types of jobs require high skills. For Kenya, the least natural resource sector activity, 44\% manufacturing, and 53\% service investments. In spite of workforce localizing policy in the hosting country, the quality of local workers and investment in the sector are keys determinants of job creation.

Table 8: FDI Job Creation Comparison by Top Ten FDI Receiving Destinations

\begin{tabular}{lcccccccccc}
\hline \hline Host & $(1)$ & $(2)$ & $(3)$ & $(4)$ & $(5)$ & $(6)$ & $(7)$ & $(8)$ & $(9)$ & $(10)$ \\
Country & Algeria & Angola & Egypt & Kenya & Ghana & Morocco & Nigeria & S. Africa & Tunisia & Tanzania \\
\hline FDI*host & $0.852^{* * *}$ & $0.279^{* * *}$ & $0.0454^{* * *}$ & $0.0333^{* * *}$ & $0.0326^{* * *}$ & $0.0253^{* * *}$ & $0.0160^{* * *}$ & $0.0158^{* * *}$ & $0.0141^{* * *}$ & $0.0126^{* * *}$ \\
& $(0.026)$ & $(0.015)$ & $(0.0014)$ & $(0.0013)$ & $(0.002)$ & $(0.001)$ & $(0.0007)$ & $(0.000)$ & $(0.0007)$ & $(0.0009)$ \\
Constant. & $1.206^{*}$ & 0.398 & $2.670^{* * *}$ & $1.455^{* * *}$ & $3.103^{* * *}$ & $2.946^{* * *}$ & $2.720^{* * *}$ & $2.491^{* * *}$ & $3.472^{* * *}$ & $2.509^{* * *}$ \\
& $(0.699)$ & $(0.743)$ & $(0.852)$ & $(0.445)$ & $(0.848)$ & $(0.33)$ & $(0.414)$ & $(0.243)$ & $(0.444)$ & $(0.803)$ \\
Number & 410 & 347 & 917 & 574 & 417 & 928 & 607 & 1,780 & 416 & 289 \\
R-Squared & 0.866 & 0.861 & 0.737 & 0.693 & 0.759 & 0.742 & 0.71 & 0.706 & 0.741 & 0.759 \\
Time & Yes & Yes & Yes & Yes & Yes & Yes & Yes & Yes & Yes & Yes \\
Sector & Yes & Yes & Yes & Yes & Yes & Yes & Yes & Yes & Yes & Yes \\
Firm & Yes & Yes & Yes & Yes & Yes & Yes & Yes & Yes & Yes & Yes \\
Origin & Yes & Yes & Yes & Yes & Yes & Yes & Yes & Yes & Yes & Yes \\
Interactions & Yes & Yes & Yes & Yes & Yes & Yes & Yes & Yes & Yes & Yes \\
\hline
\end{tabular}

Although the host countries received different volume of FDI inflow; the type of projects, local labor quality, and workforce localizing policy in place are fundamental mechanism behind FDI job creation differences in host countries. Significance level: $* * * \mathrm{p}<0.01, * * \mathrm{p}<0.05, * \mathrm{p}<0.1$.

Table 9, the sub-regional comparison of FDI job creation coincides with the result in table 8 where results

\footnotetext{
${ }^{1}$ The host country can influence the volume of job creation from the MNEs through a policy for requiring foreign firm to hire the local workers and quality of local workers can also be the source of MNE's job creation disparity across destinations.
} 
reveal that FDI generates more jobs in Algeria followed by Angola. The results show that FDI creates the highest jobs in the Central and North follow by east of Africa. The West and South are the least benefiting regions of all sub-regions in Africa. FDI creates more jobs in the Central part relative to other parts of Africa followed by the Northern part. According to this result, the least benefiting region from FDI inflow is the West part of Africa. These FDI job creation discrepancies in the regions are due to type of investments in an industry, education quality, and policies. Generally, in Africa, foreign workers are predominant in foreign companies, especially low-quality human capital countries and politically unstable countries.

South Africa has received the highest number of FDI inflow comparing to other African countries and what made it attractive to FDI inflow might include its economic development, market size, peace, quality education, and spoken-English language. However, the FDI inflow impact on job creation is still small. The northern part where market size and better education quality made more attractive to FDI inflow, it reaps the highest employment benefits from it. The central part of Africa has the highest impact on job creation from FDI and it also received the smallest number of investments compared to other regions. Central African countries received the smallest number of FDI and its least developed part of Africa

Table 9: FDI Job Creation Comparison by Sub-Regions

\begin{tabular}{lccccc}
\hline \hline Variables & Central & Northern & Eastern & Southern & Western \\
\hline FDI*Region & $0.732^{* * *}$ & $0.250^{* * *}$ & $0.368^{* * *}$ & $0.180^{* * *}$ & $0.131^{* * *}$ \\
& $(0.034)$ & $(0.004)$ & $(0.006)$ & $(0.003)$ & $(0.0031)$ \\
Constant & $1.802^{* * *}$ & $2.918^{* * *}$ & $1.786^{* * *}$ & $2.321^{* * *}$ & $2.773^{* * *}$ \\
& $(0.652)$ & $(0.17)$ & $(0.307)$ & $(0.202)$ & $(0.319)$ \\
Observations & & & & & \\
R-Squared & 340 & 2,832 & 2,145 & 2,722 & 1,577 \\
Firm & 0.827 & 0.725 & 0.755 & 0.74 & 0.733 \\
Industry & Yes & Yes & Yes & Yes & Yes \\
Project Type & Yes & Yes & Yes & Yes & Yes \\
Home country & Yes & Yes & Yes & Yes & Yes \\
Year & Yes & Yes & Yes & Yes & Yes \\
Interactions & Yes & Yes & Yes & Yes & Yes \\
\hline
\end{tabular}

Notes: FDI is logged of FDI inflow. The study interrelates the logged FDI inflow with sub-regions of Africa to compare the impact of regions on project's job creation. Categorizing African countries sub-regionally doesn't make much economic sense because the countries in the same sub-region of Africa are at different levels of economic development, education quality, and other socioeconomic factors. Significance level: $* * * \mathrm{p}<0.01, * * \mathrm{p}$ $<0.05, * \mathrm{p}<0.1$.

\subsection{Instrumental Variables (IV) Estimation}

In this part, this chapter used the instrumental variable (IV) to address potential endogeneity that may be originated from simultaneity since Greenfield data was collected in real-time as announced by a company. The investment amount of capital and the number of job creation was announced at the same time; this may cause reverse causality. The number of employees needed to carry out the projects could influence the amount of capital invested by the firms. For instance, the firm matches the number of workers and the amount of capital required by the project, where the number of workers needed by the project might determine the amount of investment. Therefore, to address this endogeneity, the instrumental variable was used to address the possible reverse causality between an independent and dependent variable. A good instrumental variable should not have a direct relationship with the dependent variable but through independent variable, Silwal (2016). On the other hand, the instrumental variable should have a direct relationship with explanatory variable. For comparative analysis, the researcher applies the exchange rates of two countries (South Africa \& Nigeria) as samples for instrumental variables.

The exchange rate can be described as the domestic currency price of a foreign currency and the level of exchange rate and its volatility influence to the amount of FDI inflow (Froot \& Stein, 1991; Kosteletou \& Liargovas, 2000; Lily, el.at, 2014). exchange rate greatly influences FDI inflow and it has a direct impact through inflation and interest rate while affecting job creation indirectly. This satisfies the requirement of a good instrumental variable. The exchange rate data were obtained from the Central Bank of South Africa and Nigeria. The data is the monthly average of the exchange rate over 14.5 years (2003-June 2017). Table 10 is the first stage of the 2SLS results, showing a positive and significant relationship between greenfield FDI inflow and the exchange rate of the host country, while changes are negligible throughout technical data manipulations (see column 1 to 7). Besides showing a positive and statistically significant relationship, the F-statistic of the first stage result is notably above the rule of thumb value of 10 as recommended, implying the exchange rate of the host country is a good IV on Greenfield FDI inflow. 
Table 10: First Stage of the 2SLS Instrumental Variable Estimation Results

\begin{tabular}{|c|c|c|c|c|c|c|c|}
\hline \multirow[b]{2}{*}{ Variables } & \multicolumn{7}{|c|}{ Log of FDI Inflow } \\
\hline & (1) & $(2)$ & (3) & (4) & (5) & (6) & (7) \\
\hline Exchange Rate & $\begin{array}{c}0.00642 * * * \\
(0.00202)\end{array}$ & $\begin{array}{c}0.00662 * * * \\
(0.00186)\end{array}$ & $\begin{array}{c}0.00286 * * * \\
(0.000512)\end{array}$ & $\begin{array}{l}0.00637^{* * *} \\
(0.00201)\end{array}$ & $\begin{array}{c}0.00982 * * * \\
(0.00242)\end{array}$ & $\begin{array}{c}0.00643 * * * \\
(0.00201)\end{array}$ & $\begin{array}{c}0.00450^{* * *} \\
(0.00056)\end{array}$ \\
\hline Constant & $\begin{array}{c}1.924 \\
(1.324)\end{array}$ & $\begin{array}{c}2.131 * * * \\
(0.397)\end{array}$ & $\begin{array}{c}3.581 * * * \\
(1.313)\end{array}$ & $\begin{array}{l}1.956 \\
(1.32)\end{array}$ & $\begin{array}{c}1.454 \\
(1.574)\end{array}$ & $\begin{array}{c}2.718^{* *} \\
(1.335)\end{array}$ & $\begin{array}{c}2.581 * * * \\
(0.0392)\end{array}$ \\
\hline Observations & 2,387 & 2,387 & 2,387 & 2,387 & 2,387 & 2,387 & 2,387 \\
\hline R-squared & 0.426 & 0.389 & 0.425 & 0.425 & 0.122 & 0.418 & 0.026 \\
\hline Country of Origin & Yes & No & Yes & Yes & Yes & Yes & No \\
\hline Host Country & Yes & Yes & No & Yes & Yes & Yes & No \\
\hline Industry & Yes & Yes & Yes & No & Yes & Yes & No \\
\hline Firm & Yes & Yes & Yes & Yes & No & Yes & No \\
\hline Year & Yes & Yes & Yes & Yes & Yes & No & No \\
\hline Interactions & Yes & Yes & Yes & Yes & Yes & Yes & No \\
\hline F-statistics & 10.16 & 12.6 & 31.2 & 10.07 & 16.45 & 10.18 & 64.47 \\
\hline
\end{tabular}

Notes: due to data unavailability for IV variable, only South Africa and Nigeria exchange rate were applied. Dropping control variables one by one to show their respective effects on the result, indicates negligible change while maintaining the positive \& significant relationship. Significance level: $* * * p<0.01, * * p<0.05, * p<0.1$.

The paper applies the Two-Stage Least Squares (2SLS) model to address the possible endogeneity instrumenting FDI Inflow as a baseline. The second stage results of the 2SLS are presented in Table 11. The positive and significant outcomes imply that the exchange rate is a good predictor of FDI inflow in Africa. Column 1 is the baseline result using the OLS technique, while columns 2 to 8 are IV results. The results are robust showing consistency with baseline results while the most influential control variable remain industry (see column 5) as shown in the basic model (see table 4). As it shows, there is consistency with the baseline result and instrument, implying the result is robust.

Table 11: Second Stage of the 2SLS Instrumental Variable Estimation Results

\begin{tabular}{lcccccccc}
\hline \hline \multirow{2}{*}{ Variables } & \multicolumn{7}{c}{ Log of Created Jobs by FDI Inflow } \\
\cline { 2 - 10 } & $(1)$ & $(2)$ & $(3)$ & $(4)$ & $(5)$ & $(6)$ & $(7)$ & $(8)$ \\
& OLS & IV & IV & IV & IV & IV & IV & IV \\
\hline \multirow{2}{*}{ Log of FDI Inflow } & $0.708^{* * *}$ & $0.701 * * *$ & $0.694 * * *$ & $0.707 * * *$ & $0.613 * * *$ & $0.714^{* * *}$ & $0.702^{* * *}$ & $0.615^{* * *}$ \\
& $(0.0141)$ & $(0.0132)$ & $(0.0133)$ & $(0.0132)$ & $(0.0132)$ & $(0.0135)$ & $(0.0132)$ & $(0.0136)$ \\
Constant & $2.377 * * *$ & $2.527 * * *$ & $2.624 * * *$ & $2.595 * * *$ & $2.544 * * *$ & $2.743 * * *$ & $2.225^{* * *}$ & $2.178^{* * *}$ \\
& $(0.751)$ & $(0.382)$ & $(0.192)$ & $(0.383)$ & $(0.382)$ & $(0.419)$ & $(0.374)$ & $(0.0434)$ \\
Observations & & & & & & & & \\
R-squared & 2,387 & 2,387 & 2,387 & 2,387 & 2,387 & 2,387 & 2,387 & 2,387 \\
Country of Origin & 0.733 & 0.706 & 0.684 & 0.704 & 0.706 & 0.53 & 0.703 & 0.46 \\
Firm & Yes & Yes & No & Yes & Yes & Yes & Yes & No \\
Industry & Yes & Yes & Yes & No & Yes & Yes & Yes & No \\
Host country & Yes & Yes & Yes & Yes & No & Yes & Yes & No \\
Year & Yes & Yes & Yes & Yes & Yes & No & Yes & No \\
Interactions & Yes & Yes & Yes & Yes & Yes & Yes & No & No \\
\hline
\end{tabular}

Notes: due to data unavailability for IV variable, only South Africa and Nigeria exchange rates were applied. Significance level: *** $\mathrm{p}<0.01, * * \mathrm{p}<0.05, * \mathrm{p}<0.1$.

Column 1 and 2 in Table 11 are full samples of a base (OLS) and IV outcomes showing a positive and statistically significant estimate at a one-star percent significance level suggesting the existence of a positive relationship between FDI inflow, the exchange rate of the host country and job creation from FDI inflow. The IV results are consistent with the OLS basic outcome of this study in Table 4.

\section{Conclusion and Policy Implications}

Last two decades, FDI inflow to Africa had increased after African countries desperately exert themselves to attract more investment inflows, which contributed so much development to the continent. The benefits FDI inflow brings 
to the host country include; job creation for locals, stimulating economic growth, transferring technology and knowledge, and most importantly, a doorway to the development of Africa.

This work examined the essential factors influencing the employment benefits from FDI inflow to Africa. Among policymakers and international organizations, job creation is a hotly discussed topic in Africa but it remains unsettled. Therefore, the analyzed the factors that determine job creation from FDI projects. The analysis includes the effects of the home country, the host country, industry, and sub-regional effects on the firm's job creation. The study employed the Ordinary Least Squared (OLS) model for the main results using cross-sectional firm-level data of Greenfield FDI from Financial Times. The study also uses Two-Stage Least Squared (2SLS) techniques for an instrumental variable using the monthly exchange rate of South Africa and Nigeria from the central banks of these two countries.

This paper documented the job creation magnitude of Greenfield FDI and Brownfield FDI which are incomparable, where Greenfield FDI generates massive jobs while M\&As job creation is little compared to Greenfield projects. As explained in the literature section, Greenfield FDI starts its business activity from the scratch bringing new economic activities through hiring all workers for different level positions and producing new products/services, which will have an impact on the economy. On the other hand, mergers and acquisitions are purchasing already existing projects and their economic effects have been absorbed by the economy, so M\&As investments may have a little effect on employment and that effects could be negative or positive.

Rather than using direct job creation as a key variable, the most influential factor on job creation is the type of industry that the firm engages in. The industrial sector that the MNE involves in, determines whether the firm's productivity relies on labor-intensive or capital-intensive. Naturally, the employments contribution of the three main economic sectors is totally different in magnitudes where the primary sector is the least job creating one. Manufacturing and tertiary sectors contribute more than 80 percent of total employment in the developed economies. In the developed world, the service sector is a king job creator followed by the manufacturing sector. The primary sector generates more jobs than manufacturing sector in some least developed and developing countries due to the economy that is based on primary economic activities (e.g. agricultural and livestock products).

The sub-regions' effects on job creation; the Central part of Africa collects the highest employment benefits from FDI projects followed by the Northern and Eastern, respectively. FDI inflow creates the least jobs in the Western region of Africa followed by the Southern Africa region. Central Africa received the smallest number of investments followed by the West. The FDI job creation depends on the region's human capital and sector type that MNEs invested in. The result reveals that the MNEs from UK and USA are creating fewer jobs with their projects comparing to other MNEs from India and the China. This might imply that MNEs from industrialized countries are capital-intensive than MNEs from developing countries, so MNEs from the developing create more jobs with their projects comparing to those from the developed world. The top beneficiary, Algeria has the highest rate of FDI employment benefits while the least benefiting country is Tanzania comparing to other top ten locations. On industrial sector comparison about their respective job creations, the study found that the manufacturing sector has the highest rate of job creation and the natural resource sector has the lowest rate of job creation according to data.

The study has a crucial implication for the host country. The industry sector that the MNEs invest in is an important factor that determines their employment benefits for the host economy. This is because the sector it engages in also determines labor-intensive shares and required level of labor skills. Some industries are highly capital-intensive generating fewer jobs than labor-intensive firms, while other MNEs are high skilled laborintensive that the host country may not be able to take full advantage of their employment benefits due to the lowskilled domestic labor force. Attracting international investments could help Africa in job creation if countries have a plan for inward FDI to take the full advantage it brings.

Precisely, before encouraging international investors, it is important to know the skill type of your unemployed population to invite the right companies that engage in industries in your favor. This will generate jobs your people can perform. If the governments of Africa cannot provide jobs to their citizens, they should at least provide quality education so that their citizens would be competitive in international job markets and would also be able to take advantage of jobs created by the FDI inflow to Africa. Further, the implementation of continental free trade agreements among African countries would be a great deal for capital, labor, and trade movements in which the employment opportunities will expand.

\section{References}

[1] Javorcik, B. (2013). Does FDI Bring Good Jobs to Host Countries? Background Paper for the World Development Report 2013

[2] Hijzen, A., Martins, P., Schank, Th., \& Upward, R. (2013). Foreign-owned firms around the world: A comparative analysis of wages and employment at the micro-level. European Economic Review 60 (2013) $170-188$.

[3] Hakkala, K., Heyman, F., \& Sjoholm, F. (2013). Multinational firms, acquisitions and job task. European 
Economic Review 66(2014)248-265

[4] Employment by major industry sector (2017). Employment Projections program, U.S. Bureau of Labor Statistics.

[5] Heyman, F., Sjöholm, F., \& Tingvall, G. (2007). Is there really a foreign ownership wage premium? Evidence from matched employer-employee data. Journal of International Economics 73 (2007) 355-376

[6] Bandick, R. \& Karpaty, P. (2010). Employment effects of foreign acquisition. International Review of Economics and Finance 20 (2011) 211-224

[7] Lehto, E. \& Bockerman, P. (2008). Analyzing the employment effects of mergers and acquisitions. Journal of Economic Behavior \& Organization 68 (2008) 112-124

[8] Huttunen, K., 2007. The effect of foreign acquisition on employment and wages: evidence from Finnish manufacturing. The Review of Economics and Statistics 89, 497-509.

[9] Piscitello, L. \& Rabbiosi, L., 2005. The impact of inward FDI on the local companies' labor productivity: evidence from the Italian case. International Journal of the Economics of Business 12, 35-51.

[10] Bellak, C., Pfaffermayr, M., \& Wild, M. 2006. Firm performance after ownership change: a matching estimator approach. Applied Economics Quarterly 51, 29-54.

[11] Brown, C. \& Medoff, J.L. 1988. The impact of foreign acquisition on labor. In: Auerbach, A. (Ed.), Corporate Takeovers: Causes and Consequences. University of Chicago Press, Chicago, pp. 9-25.

[12] Ollinger, M., Nguyen, S.V., Blayney, D.P., Chambers, B., Nelson, K., 2005. Effect of food industry mergers and acquisitions on employment and wages. United States Department of Agriculture. Economic Research Report No. 13.

[13] McGuckin, R.H., Nguyen, S.V., 2001. The impact of ownership changes: a view from labor markets. International Journal of Industrial Organization 19, 739-762.

[14] McGuckin, R.H., Nguyen, S.V., Reznek, A.P., 1995. The Impact of Ownership Change on Employment, Wages and Labor Productivity in US Manufacturing 1977-1987. Center for Economic Studies, Washington, DC (US Bureau of Census, Working Paper No. 95-8).

[15] Amoroso, S. \& Moncada.P.C, P. (2018). Inward Greenfield FDI and patterns of job polarization. JRC Working Papers on Corporate R\&D and Innovation No 2/2018. European Union, 2018

[16] European Commission. (2017). Greenfield Investment Monitor. In Focus: China's Expansion in the EU

[17] Karlsson, S., Lundin, N., Sjöholm, F. \& He, P. (2007). FDI and Job Creation in China. Working Paper Series Vol. 2007-24. November 2007

[18] Black, A., Craig, S. \& Dunne, P. (2016). Capital intensity, industrial policy and employment in the South African manufacturing sector. REDI3x3 Working paper 23

[19] Crivelli, E., Furceri, D. \& Toujas-Bernaté, J. (2012). Can Policies Affect Employment Intensity of Growth? A Cross-Country Analysis. IMF Working Paper. WP/12/218

[20] Chen, Zh., Ge, Y. \& Lai, H. (2010). Foreign Direct Investment and Wage Inequality: Evidence from China. World Development Vol. 39, No. 8, Pp. 1322-1332, 2011. Doi: 10.1016/J.Worlddev.2010.12.006

[21] Zulfiu, M. (2015). An Empirical Investigation of the Effects of Foreign Direct Investment on the Skill Intensity of Host Country Employment. Procedia Economics and Finance 26 (2015) 623 - 629

\section{Appendix}

This section provides further insights about data and its different angles. Unlike regression results, here the data is not logged. The extra information in this section includes maximum, minimum, median, and summary statistics for five the source countries. Moreover, in this appendix there is a table that shows the biggest lump of capital and job creation from FDI as well as sectors of these lump sums. 


\section{Overall Average of Unit FDI Job Creation}

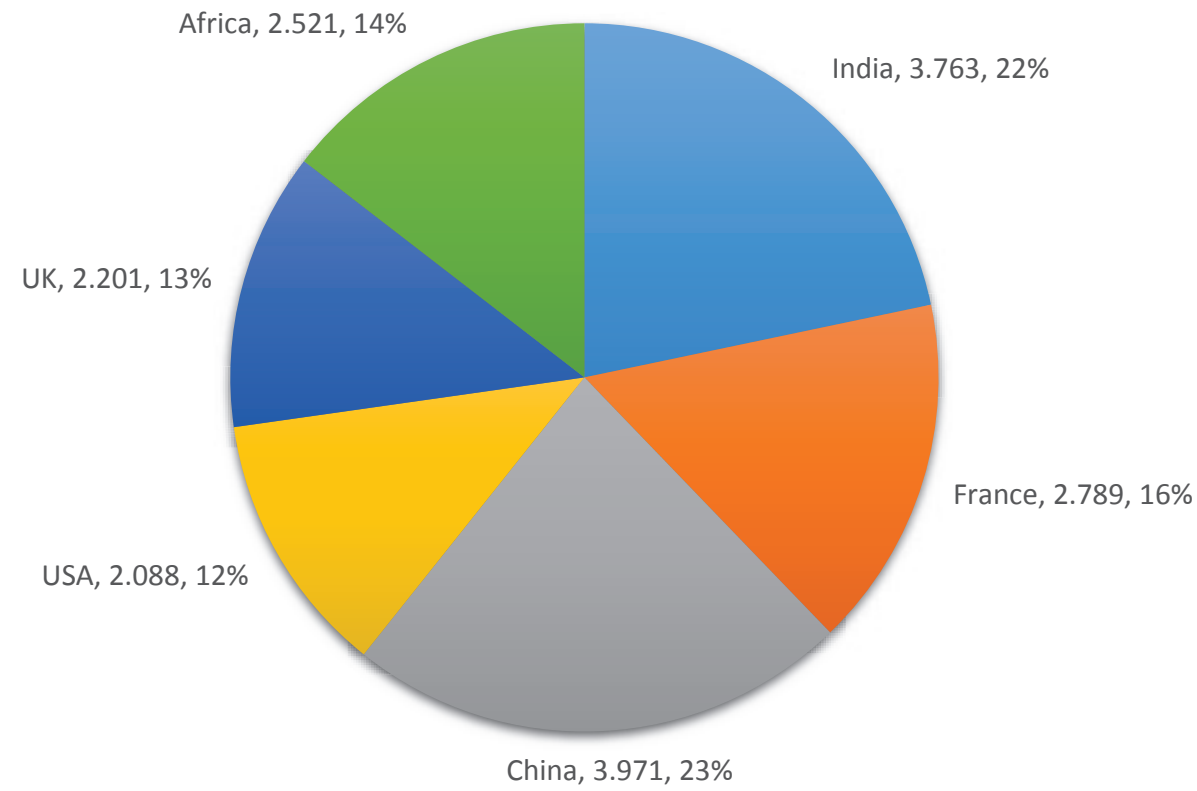

Figure (1): Average Job Creation of Per Unit FDI Inflow to Africa by MNEs Origin (2003-June 2017)

Source: author's computation

The average Job Creation per Unit FDI inflow to Africa does not necessarily represent the real outcome of FDI job creation because there are other factors that influence its job creation magnitude in both the host and origin countries, which need to be controlled in their fixed effects. As shown in the model specification section as well as in the empirical results where many variables were controlled; this result is just jobs divided by FDI inflow to compare with countries whose FDI has high ratio of job creation in Africa and vice versa. As result indicates Chinese and Indian enterprises have higher job creation ratio than the US, UK, and France.

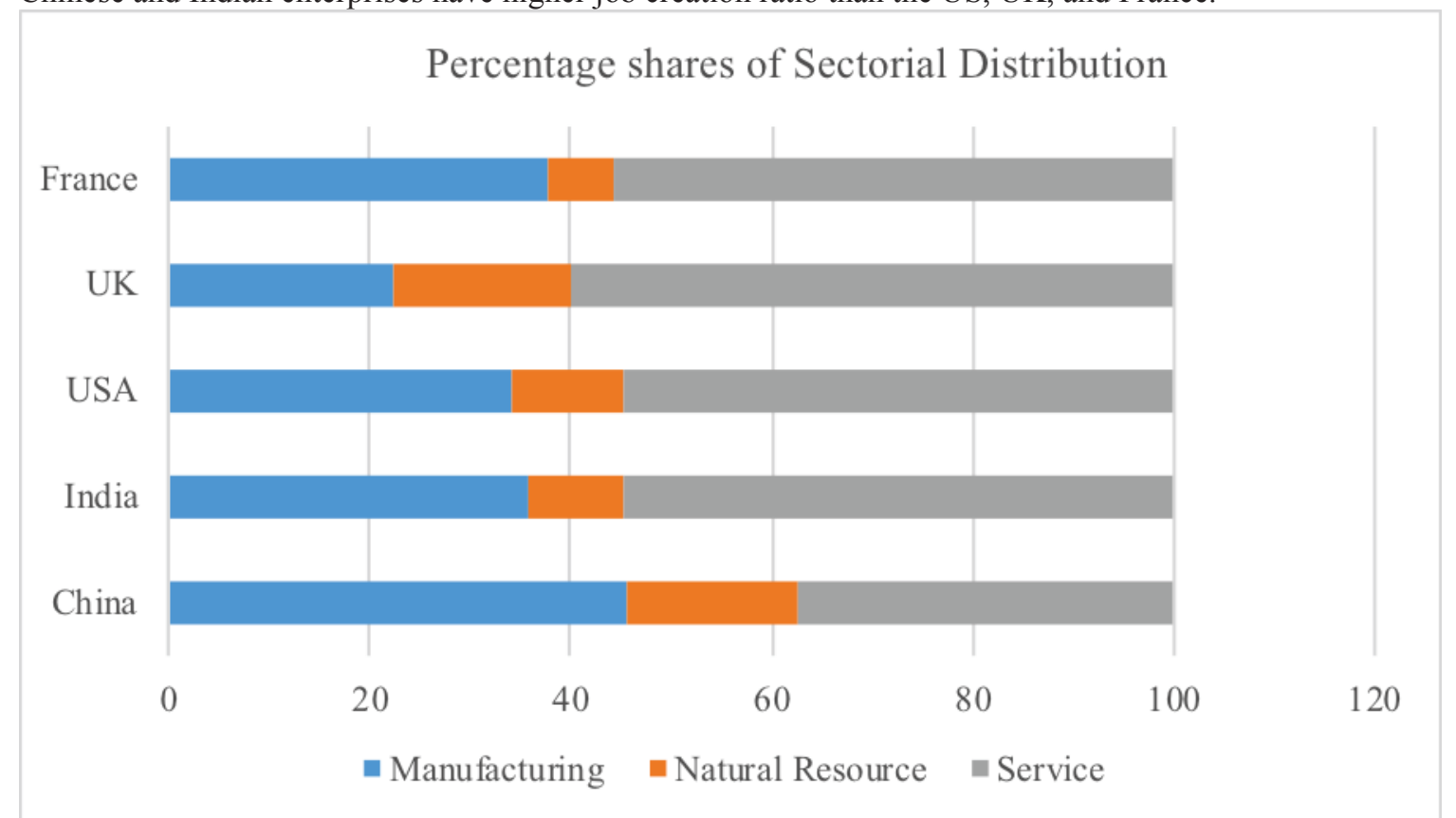

Figure (2): MNEs' Sector Concentration by Origin Countries (2003-2017)

Source: author's computation 


\section{Sectorial percentage shares}

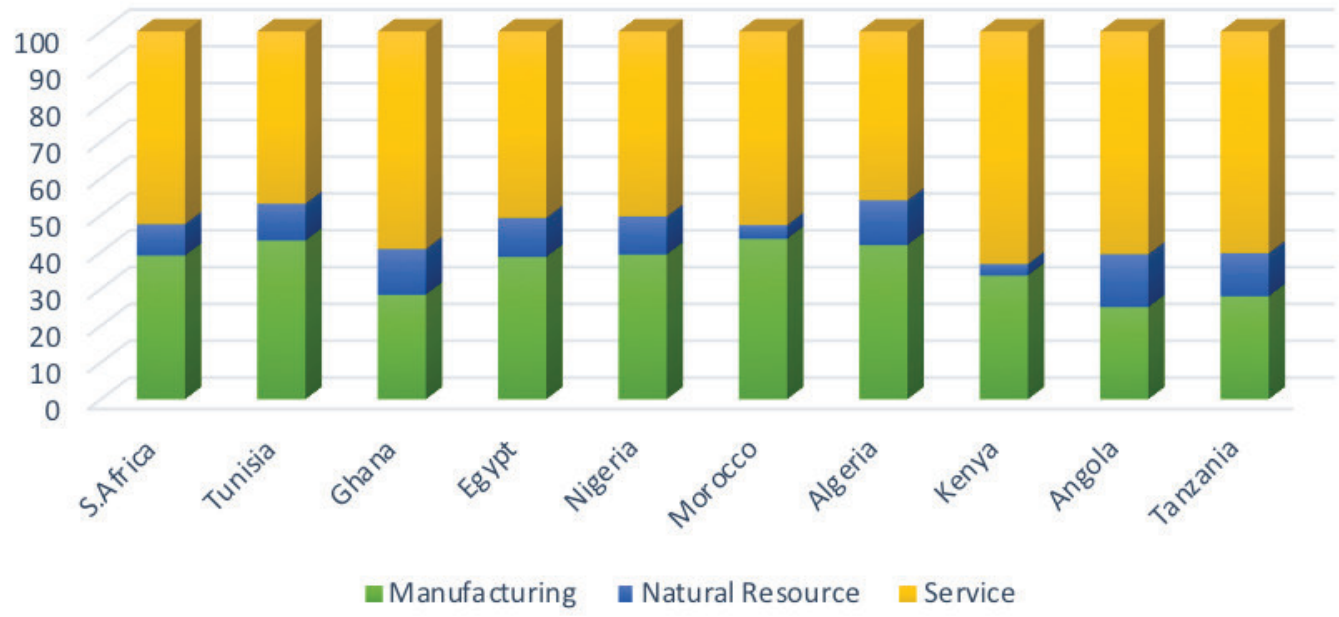

Figure (3): Top Ten FDI Host Countries by Sectorial Distribution

Source: author's computation

Table (1): Detailed Summary Statistics (Job creation) 2003-June 2017

\begin{tabular}{lccccccc}
\hline \hline Year & Variable & $\mathrm{N}$ & Mean & SD & Median & Min & Max \\
\hline 2003 & Jobs & 336 & 289.85 & 466.18 & 130 & 1 & 5000 \\
2004 & Jobs & 276 & 264.22 & 403.95 & 128 & 0 & 3000 \\
2005 & Jobs & 447 & 301.11 & 502.23 & 122 & 1 & 3000 \\
2006 & Jobs & 473 & 227.77 & 499.46 & 50 & 1 & 5000 \\
2007 & Jobs & 414 & 273.45 & 700.94 & 76.00 & 3 & 7981 \\
2008 & Jobs & 887 & 273.26 & 540.95 & 86 & 0 & 6000 \\
2009 & Jobs & 770 & 176.62 & 427.35 & 38.5 & 0 & 5000 \\
2010 & Jobs & 714 & 192.70 & 392.54 & 45 & 1 & 3500 \\
2011 & Jobs & 952 & 180.07 & 370.70 & 42.5 & 0 & 3000 \\
2012 & Jobs & 880 & 138.24 & 377.46 & 22 & 1 & 6000 \\
2013 & Jobs & 931 & 150.81 & 356.38 & 48 & 0 & 6000 \\
2014 & Jobs & 795 & 217.55 & 685.47 & 40 & 1 & 13000 \\
2015 & Jobs & 792 & 190.13 & 450.17 & 40 & 1 & 5000 \\
2016 & Jobs & 674 & 191.15 & 486.54 & 50 & 0 & 4000 \\
2017 & Jobs & 275 & 205.01 & 464.01 & 51 & 3.00 & 3000 \\
\hline
\end{tabular}

Notes: The data in 2017 is only six months (Jan-June). Measuring Unit is in thousand US Dollars.

Source: author's computation 
Table (2): Detailed Summary Statistics (Greenfield FDI Inflow) (2003-2017)

\begin{tabular}{cccccccc}
\hline \hline Year & Variable & $\mathrm{N}$ & Mean & SD & Median & Min & Max \\
\hline 2003 & FDI & 336 & 152.67 & 367.59 & 26.95 & 0.4 & 3400 \\
2004 & FDI & 276 & 124.08 & 398.24 & 22.2 & 0.13 & 4000 \\
2005 & FDI & 447 & 136.25 & 388.86 & 24.2 & 0.124 & 5400 \\
2006 & FDI & 473 & 153.28 & 983.66 & 12.3 & 0.05 & 20000 \\
2007 & FDI & 414 & 129.36 & 422.38 & 13.97 & 0.5 & 5400 \\
2008 & FDI & 887 & 157.40 & 636.08 & 15.3 & 0.03 & 15000 \\
2009 & FDI & 770 & 110.74 & 460.79 & 11 & 0.045 & 9000 \\
2010 & FDI & 714 & 102.42 & 372.07 & 11.8 & 0.07 & 5000 \\
2011 & FDI & 952 & 73.13 & 241.67 & 11 & 0.014 & 4000 \\
2012 & FDI & 880 & 55.69 & 218.27 & 11 & 0.02 & 3600 \\
2013 & FDI & 931 & 73.40 & 230.53 & 11.8 & 0.06 & 4000 \\
2014 & FDI & 795 & 112.92 & 672.70 & 11 & 0.3 & 16000 \\
2015 & FDI & 792 & 84.66 & 306.90 & 11.08 & 0.11 & 6000 \\
2016 & FDI & 674 & 139.51 & 909.35 & 11.9 & 0.03 & 20000 \\
2017 & FDI & 275 & 46.53 & 111.65 & 11.9 & 0.49 & 1500 \\
\hline
\end{tabular}

Notes: The data in 2017 is only six months (Jan-June). Measuring Unit is per million US Dollars.

Source: author's computation

Table (3): Summary Statistics of Five Source Countries

\begin{tabular}{|c|c|c|c|c|c|}
\hline COUNTRY & MEAN & SD & MEDIAN & MIN & MAX \\
\hline \multicolumn{6}{|l|}{$U \boldsymbol{S A}$} \\
\hline FDI & 2.75 & 1.60 & 2.40 & -2.23 & 8.29 \\
\hline Jobs & 3.90 & 1.42 & 3.69 & 0.00 & 8.16 \\
\hline \multicolumn{6}{|l|}{ China } \\
\hline FDI & 3.40 & 1.93 & 3.10 & -3.91 & 9.90 \\
\hline Jobs & 4.90 & 1.63 & 4.98 & 1.10 & 8.52 \\
\hline \multicolumn{6}{|l|}{ France } \\
\hline FDI & 2.83 & 1.55 & 2.40 & -1.80 & 9.68 \\
\hline Jobs & 4.13 & 1.39 & 3.99 & 0.00 & 8.70 \\
\hline \multicolumn{6}{|l|}{ India } \\
\hline FDI & 3.01 & 1.60 & 2.48 & -1.47 & 8.16 \\
\hline Jobs & 4.36 & 1.52 & 4.00 & 0.00 & 8.01 \\
\hline \multicolumn{6}{|l|}{$\boldsymbol{U} \boldsymbol{K}$} \\
\hline FDI & 2.92 & 1.59 & 2.40 & -2.30 & 8.52 \\
\hline Jobs & 3.93 & 1.47 & 3.61 & 0.00 & 8.52 \\
\hline
\end{tabular}

China has the highest values of mean and standard deviation both in FDI and job creation compared to the other countries. Data was logged in this table so as to apply empirical results of these five countries (see table 4.6). Source: author's computation 
Table (4): The Largest Lump Sum of Capital \& Job Creation by Sectors

\begin{tabular}{lccc}
\hline & & Economic Sectors & \\
\cline { 2 - 4 } Variables & Manufacturing & Primary & Service \\
\hline Treatment & 2160 & & 8500 \\
Capital investment & 2300 & 6000 & 9000 \\
& 3700 & 6000 & 20000 \\
& 5200 & 15000 & 20000 \\
Outcome & & 16000 & 4000 \\
Job Creations & 6000 & 3000 & 5000 \\
& 6000 & 3000 & 6000 \\
\end{tabular}

Throughout this job creation chapter, primary represents natural resource. The FDI is in millions of US dollars and job creation is in thousands. Source: author's computation

This table indicates the largest lump sum amount of capital flew to Africa during the sample period and its particular sector as well as number of jobs it created. Manufacturing received the smallest lump sum compared to other sectors but manufacturing companies generate more jobs with their projects than any other sector.

\section{Acknowledgements}

This paper was financially supported by the Chinese Scholarship Council (CSC), Somali National University, and Mr. Abukar Salad Warsame. This work was reviewed at Southwestern University of Finance \& Economics by anonymous reviewers.

Last but not least, I would like to extend my sincere gratitude to Prof. Zhang Jipeng for the continuous guidance and invaluable research-related support during the writing. Highly appreciated your support and services. I am grateful to you all! 